\title{
An Investigation of Children's Museums in the United States -- Their Past, Present and Future: A Proposed Study
}

\section{Herminia Weihsin Din}

\section{Introduction}

Most American museums in the middle of the nineteenth century were established for the purposes of collection, preservation, and exhibition of art, natural specimens, and cultural artifacts. These traditional museums encouraged learning through passive listening and seeing, and not by interaction with the object. They were designed primarily for adults' interests and children were expected to visit the museums and enjoy them as adults did. There was nothing special or unique for children until the Brooklyn Children's Museum opened its doors on December 16, 1899. This museum was dedicated as a place especially for children to learn, to discover, and to satisfy their natural curiosity. Its opening marked the beginning of the development of children's museums in the United States.

Across one hundred years of history, the evolution of children's museums has been enthusiastically supported and recognized by parents, educators, community leaders, and boards of education, and all were involved in the development of children's museums. Consequently, there was a continuing demand for the establishment of children's museums, which became the fastest growing branch of the museum community. For instance, there were over 40 children's museums, youth museums or junior museums by the $1960 \mathrm{~s}$. The number doubled during the 1970s and 1980s and more than 70 children's museums have opened to the public between 1990 and 1997. About a dozen children's museums are scheduled to open in the next five years.

A review of the literature discovered few studies that focus on the context of children's museums development, while comparatively more studies are available regarding descriptive information or historical facts. For instance, Selina Johnson had investigated the origins, relationships, and cultural contributions of museums for youth in the United States in $1962 .{ }^{1}$ However, this study was finished before the revolution of children's museum movement, when Michael Spock, who became the head of the Children's Museum in Boston in 1963, redefined the philosophy of children's museums and promoted participatory and interactive learning. ${ }^{2}$ Several other studies focused on the dynamics of selected children's museums, the development and status of science centers and museums for children, school museums in the United States, examination of selected characteristics of hands-on children's museum, and so on. ${ }^{3}$ This lack of extended research within the context of children's museums development suggests a need for further in-depth research investigation in the area. ${ }^{4}$ 


\section{Purpose of the Study}

The purpose of this study is to identify how changes in educational theories, social, and cultural issues have affected the movement of children's museums during its almost one hundred years of evolution. In order to understand the broad context within which children's museum development occurred, this study intends to present a history of the children's museum movement in general, instead of specifying the development of each individual museum.

This study also addresses the potential and importance of children's museums and their connection to the principles and delivery of art education and museum education in art museums. As we know, a central concept of teaching the arts is to create a learning experience that is meaningful for students by incorporating knowledge across art history, criticism, aesthetics, studio production, and cultural aspects. In order to make the learning process more interesting, more relevant, and more rewarding, the foundation of teaching art is to facilitate students to make connections from one idea to another, especially in relation to their lives. Art education relies on student-centered pedágogies.

The ideology at the children's museum is parallel to the discipline of art education. Generally, children's museum practices reflect the philosophy of "learning by doing," engage contextual understanding, emphasize participatory learning experience, focus on a thematic approach in programming and exhibition design, promote cultural diversity, and provide community services. Children's museums are designed specifically for children to learn, to spark their curiosity and imagination, and to have a holistic understanding of themselves and the world around them. Therefore, a study of the history of children's museums can add to the body of knowledge regarding the causal relationship among social, cultural, and political forces affecting art education and museum education in art museums.

\section{Research Questions}

The primary research goal of this study is to understand what a children's museum is and its relation to educational, social, and cultural issues that have affected the development of children's museums by examining the following research questions:

1. What were the motivations and initiatives for developing children's museums?

2. How have educational theories, social, and cultural issues affected the development of children's museums?

3. What were the reasons for the rapid growth in children's museums after the 1960s?

4. How have been the philosophies of exhibition design changed through the historical development of children's museums?

5. What are the congruencies among the discipline of art education, museum education in art museums, and children's museum practices? 


\section{Methodology}

According to Walter Borg and Meredith Gall, "historical research involves the systematic search for facts relating to questions about the past and the interpretation of these facts. ${ }^{15}$ Foster Wygant also believes that historical research can describe the main research target not only in terms of an overview of the beginning and introduction of its main developments, but can also examine these movements in a variety of contexts. ${ }^{6}$ Therefore, this study was conducted as historical research in the period between 1899 and 1997 to draw a picture of how the children's museums evolved in the United States. To achieve a better understanding of the context of the children's museum movement, the research procedures of this study were identified as follows:

The first step was to define the research population by cross-examining various resources as the Museum Index, Association of Youth Museum Membership Directory, etc. Two basic categories--"children's museum" and "open to the public"--were used to prepare a chronological list of children's museums. Under these two categories, there were approximately 200 children's museums selected to be a part of this study. Although some of these museums had closed, merged, or changed their name and/or focus to become different types of institutions over the course of their existence.

Data used for this study were gathered mainly from primary resources such as information provided directly by children's museums and archival documents related to children's museum development. Due to the massive quantity of data, this study applied external and internal criticism to evaluate the information that was gathered and used. ${ }^{7}$ The procedures of data gathering were as follows:

First, there was one request letter sent to each of the 200 children's museums identified, according to the list, asking for museum information on its history, mission statement, philosophy of education and exhibition design, etc. The response rate to this letter was $53 \%$. The information typically provided by children's museums included the museum's historical background, mission statement, philosophical and theoretical approach, description of exhibitions, annual reports, pamphlets, brochures, etc. Second, Internet access was considered as another primary resource to gather direct information on each children's museum, and some resource organizations have launched home pages on the World Wide Web with similar information as above mentioned. Third, other printed materials that were gathered were publications from the Association of Youth Museums, the Association of American Museums, and articles from journals, magazines, newspapers, theses, dissertations, etc. Fourth, subscribing to mailing list from the museum newsgroup and using electronic mail provided an alternative access to current inquiry in the field of children's museums. Fifth, several field trips were conducted during the time of this study to various museums, thus personal observation and interviews with museum staff members also were considered as supplementary information.

All these data have been organized into two major computer databases. One is the Children's Museum Database that contains close to 200 museums with 
demographic information, historical background, mission statement, and descriptions of exhibitions and programs, etc. Another one is the Reference Database that includes more than 250 records of bibliographic information of articles, correspondence, letters, and unpublished documents that are related to the development of children's museums.

The interpretation of data was based on the research questions by following the principles of inductive analysis ${ }^{8}$ and empathic neutrality approach. ${ }^{9}$ In addition, this study attempted to avoid "presentism"--a form of bias that tends to use current points of view to interpret the past when doing a historical interpretation. ${ }^{10}$ With focus on the motivations for children's museums establishment, mission statement, impacts from various educational theories and practices and the changing of social and cultural environments, this study examined four periods of the children's museums development. They were:

1. Derivation and Innovation (1899-1928);

2. The Importance of Children's Leisure, Institutional Sponsorship, and Community Joint Endeavors on the Development of Children's Museums (1929-1957);

3. Redefining the Philosophy of Children's Museums (1958-1980); and Blossoming Development Nationwide (1981-1997).

These four periods were adopted because they reflect the broad historical shifts among applications of educational theory and learning strategy; changes in social and cultural aspects; philosophical approaches to exhibition and program design; and the significance of children's museums in relation to the community.

\section{Limitations of the Study}

This research is limited to the study of special characteristics of children's museums as they serve the needs of children. Many other institutions, such as natural science museums or science centers, art centers or art museums, discovery rooms, history museums or historical houses, zoos, and national parks were excluded from this study. Although they frequently have children's discovery room, gallery, or provide programs, exhibitions, or workshops for children and families, their major focus is on both adults and families rather than on children from toddlers to young adolescents.

In addition, at least two technical dilemmas existed in the searching process. First, most of the children's museums did hot document detailed background information concerning the motivations, philosophies, needs, and commitments to create such programs or exhibits. ${ }^{11}$ Second, certain archival documents, i.e. earlier articles or research studies, were not available even through inter-library loan because the library that owns the item will not loan or copy the material. Finally, the most difficult aspect of this study was to generate a truly natural and objective interpretation, as the researcher came from a different cultural background from the cultures typically represented by those who formed these children's museums. 


\section{Significance of the Study}

A Chinese proverb says, "Everything we learn from history will lead us to success in the future." Very little research has focused on the relationships between the multiple impacts of the variables previously mentioned. The significance of this historical investigation lies in the attempt to explore the further possible collaboration among art education, children's museums, and museum education in art museums. With its presentation of the origins of children's museums, and application of educational theories and methods in those institutions, this study provides valuable additional information regarding the current practices of art education as well as museum education in art museums. In addition, this study is intended to serve as a commemoration of children's museum centennial anniversary in the United States in 1999.

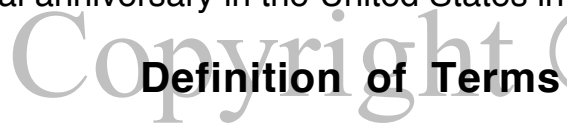

Children's Museum -- The Association of Youth Museums' definition is "A children's museum is an institution serving the needs and interests of children by providing exhibits and programs which stimulate curiosity and motivate learning. Children's museums are organized and permanent non-profit institutions, essentially educational in purpose, with professional staff, which utilize tangible objects, care for them and exhibit them to the public on some regular schedule"12

Youth Museum and Junior Museum -- An institution primarily established from the 1930s to 60s, for children and teenagers to spend their leisure time, and cultivate their life-long hobbies in subjects mainly focused on science, natural history and arts. In order to attract a larger audience ranging from mid-elementary to high school students, the institution was named youth museum or junior museum instead of children's museum.

\section{Outline of the Chapters}

The remainder of this dissertation is organized in the following manner: Chapter 2 reviews the four earliest developed children's museums, the Brooklyn Children's Museum, and later Children's Museum of Boston, Detroit, and Indianapolis. These museums represent four different types of models, and with their pioneering experiments, they became the hallmark among exhibits, programs, and school-museum relationships for many to follow. Chapter 3 addresses issues that inspired the development of children's museums with focus on the needs for children's leisure time activity and in-school education. Additionally, the establishment of children's museums became a community project with efforts not only from the community itself but also from various individuals and institutions i.e. the Junior Leagues, and the William T. Hornaday Memorial Foundation. Chapter 4 discusses how Michael Spock redefined the philosophy of children's museums and the concept of "hands-on" by introducing the "participatory" and "interactive" learning. It also reveals several other issues that affected the development of children's museums such as the science education reform, applications of architectural concepts in exhibition or building 
itself, and further involvement of parents, teachers, and community leaders. Chapter 5 provides an overall picture of current children's museum development by exploring their styles, motivations, visions and philosophies, partnership between the children's museum and the community, and exhibit design and display. Chapter 6 summarizes the development of children's museums, elaborates the significance of this study, makes suggestions for future research, and provides recommendations relating to current practices in art education and museum education in art museums.

\section{Endnotes}

${ }^{1}$ Selina T. Johnson, "Museums for Youth in the United States: A Study of Their Origins, Relationships, and Cultural Contributions" (Dissertation. New York University, 1962).

${ }^{2}$ Linda R. Edeiken, "Children's Museums: The Serious Business of Wonder, Play, and Learning" Curator 35, 1 (1992): 21-27.

${ }^{3}$ Yvonne K. Holman, "An Investigation into the Dynamics of Children's Museums: A Case Study of Selected Museums" (Dissertation. Northern Illinois University, 1982);

Melville W. Fuller, "The Development and Status of Science Centers and Museums for Children in the United States" (Dissertation. University of North Carolina at Chapel Hill, 1970); Kathryne Mc. Speaker, "An Examination of Selected Characteristics of Hands-On Children's Museum" (Dissertation. Temple University, 1994); Palmer P. Clark, "A Historical Bibliography of Children's Museums and Works with Children in Adult Museums in the United States, 1877-1957" (Master's Thesis. Catholic University of America, 1957); Kathleen Schneider, "Children's Museums: Historical Development Current Status and Rationale for Chartering Number 148" (Master's Thesis. Bank Street College of Education, 1988); Cassandra Zervos, "Children's Museums: A Case History of the Foundations of Model Institutions in the United States" (Master's Thesis. The Pennsylvania State University, 1990); Owen K. Huges, "An Investigation of School Museums in the United States" (Master's Thesis. San Jose State College, 1968).

${ }^{4}$ Selina T. Johnson, 1962.

${ }^{5}$ Walter R. Borg and Meredith D. Gall, Educational Research: An Introduction 5th ed. (New York: Longman Publishing Company, 1989).

${ }^{6}$ Foster Wygant, Art in American Schools in the Nineteenth Century (Cincinnati: Interwood Press, 1983).

${ }^{7}$ External criticism is to raise questions about the nature of the historical resource to identify if it is original and genuine copy, and who wrote it with what conditions, etc. Internal criticism involves evaluating the accuracy of the statements that are contained in the documents. In Walter R. Borg and Meredith D. Gall, 1989.

${ }^{8}$ Inductive analysis: Immersion in the details and specifics of the data to discover important categories, dimensions, and interrelationships; begin by exploring genuinely open questions rather than testing theoretically derived (deductive) hypotheses. In Michael Quinn Patton, Qualitative Evaluation and Research Methods (California: SAGE Publication, 1990): 41. 
${ }^{9}$ Empathic neutrality approach: Complete objectivity is impossible; pure subjectivity undermines credibility; the researcher's passion is understanding the world in all its complexity--not proving something, not advocating, not advancing personal agendas, but understanding; the researcher includes personal experience and empathic insight as part of the relevant data, while taking a neutral nonjudgmental stance toward whatever content may emerge. In Michael Quinn Patton, 1990, 41.

${ }^{10}$ Carl F. Kaestle, "Recent Methodological Developments in the History of American Education" In Richard M. Jaeger (Ed.) Complementary Methods for Research in

Education (Washington, DC: American Educational Research Association, 1988); Walter R. Borg and Meredith D. Gall, 1989.

${ }^{11}$ An informal interview with Ellen Lampros conducted at the Cleveland Children's Museum, Ohio on September 1995.

${ }^{12}$ Linda R. Edeiken, 1992.
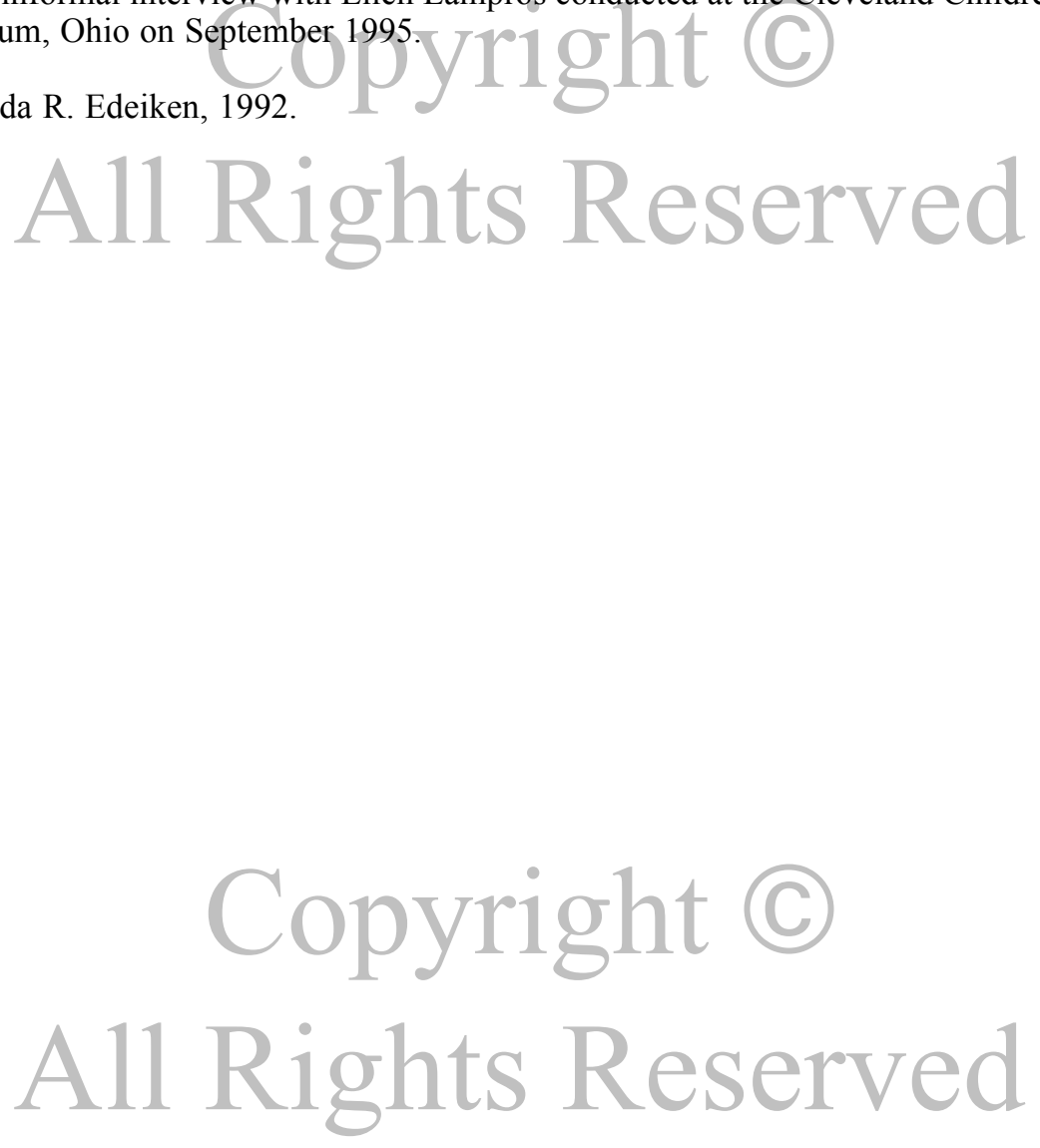